\title{
ANALISIS WILLINGNESS TO PAY PETANI TERHADAP PELAKSANAAN PROGRAM ASURANSI USAHA TANI PADI (AUTP) DI KABUPATEN ACEH BESAR
}

\section{Analysis Of Willingness To Pay Farmers On Implementation Of The Rice Farmers Insurance Program In Aceh Besar Regency}

\author{
Lukman Hakim", Muhammad Yuzan Wardhana1 ${ }^{*}$, Shinta Mulia1, \\ Sofyan $^{1}$ \\ ${ }^{1}$ Fakultas Pertanian, Universitas Syiah Kuala \\ Jln. Tgk. Hasan Krueng Kalee No. 3, Kampus USK, Banda Aceh 23111, Aceh, \\ Indonesia \\ *E-mail:yuzan@unsyiah.ac.id
}

\begin{abstract}
ABSTRAK
Kabupaten Aceh Besar merupakan salah satu wilayah sentra produksi padi di Provinsi Aceh dengan tingkat kerawanan bencana yang cukup tinggi. Jika hal ini dibiarkan terus berlanjut dikhawatirkan akan berdampak terhadap stabilitas dan ketahanan pangan daerah, khususnya produksi dan ketersediaan bahan pokok beras. Penelitian ini bertujuan menganalisis nilai Willingness To Pay dan mengidentifikasi faktor-faktor yang mempengaruhi Willingness To Pay terhadap premi asuransi usaha tani padi di Desa Tampok Blang Kecamatan Suka Makmur Kabupaten Aceh Besar. Data yang digunakan ialah data primer hasil wawancara dan observasi, sedangkan data sekunder diambil dari Dinas Pertanian dan Perkebunan Provinsi Aceh terkait Februari - Agustus 2020. Teknik analisis data yang digunakan yaitu Contingent Valuation Methode dan Persamaan Regresi Logistik. Hasil analisis menunjukkan bahwa rata-rata nilai Willingness To Pay petani terhadap premi Asuransi Usaha Tani Padi adalah sebesar Rp 33.140/Ha/MT. Faktor utama yang memengaruhi peluang kesediaan petani untuk membayar (Willingness to Pay) adalah variabel jumlah tanggungan dan pendapatan. Pengalaman bertani, luas lahan dan status lahan tidak berpengaruh secara signifikan terhadap kesediaan petani responden untuk membayar (Willingness To Pay) premi AUTP. Disarankan agar adanya kesetaraan pengetahuan dan koordinasi informasi antara petani dan semua pihak terkait dalam program AUTP. Hal tersebut dapat dilakukan dengan menambah pertemuaan penyuluhan serta sosialisasi kepada para petani.
\end{abstract}

Kata kunci: Padi Sawah, Asuransi Usaha Tani Padi (AUTP), Willingnes To Pay (CVM), Contingent Valuation Methode (CVM), Premi. 


\begin{abstract}
Aceh Besar Regency is one of the rice production centers in Aceh with a fairly high level of disaster vulnerability. If this is allowed to continue, it is feared that it will have an impact on regional food stability and security, in particular the production and collection of the staple rice. This study aims to assess the Willingness to Pay and to identify the factors that affect the willingness to pay for rice farming insurance in Tampok Blang Village, Suka Makmur District, Aceh Besar Regency. The data used are primary data from interviews and observations, while secondary data was taken from the Agriculture and Plantation Service Office of Aceh Province regarding February - August 2020. The data analysis technique used was the Contingent Assessment Method and Logistic Regression. The analysis showed that the average value of Willingness to Pay The main factor affecting the opportunity of farmers willingness to pay (Willingness to Pay) is the variable number of dependents and income. Farming experience, land area and land status do not significantly influence farmers' willingness to pay (Willingness To Pay) premium AUTP. It is suggested that there is equality of knowledge and information coordination between farmers and all parties involved in the AUTP program. Equality of knowledge and coordination can be done by adding extension meetings and outreach to farmers.
\end{abstract}

Keywords: Lowland Rice, Rice Farming Insurance Program, Willingnes To Pay (CVM), Contingent Valuation Method (CVM), Premi.

\title{
PENDAHULUAN
}

Indonesia merupakan negara agraris yang memegang peranan penting dalam sektor pertanian. Peranan sektor pertanian dapat dikatakan sebagai mata pencaharian utama bagi hampir sebagian besar masyarakat Indonesia. Kabupaten Aceh Besar merupakan salah satu daerah sentral produksi padi di Provinsi Aceh. Berdasarkan data yang dirangkum oleh ([BPS] 2018), menunjukkan perkembangan luas tanam dan produksi padi di Kabupaten Aceh Besar cenderung mengalami fluktuasi selama tahun 2009 hingga 2018. Penurunan tertinggi terjadi pada tahun 2013, dimana produksi padi mengalami penurunan sebesar 21,63 persen dari tahun sebelumnya. Produksi padi tertinggi terjadi pada tahun 2010 dimana jumlah produksi mencapai 274,461 Ton atau naik sebesar 10,67 persen dari tahun sebelumnya. Jika ditinjau dari tingkat luas tanamnya, terlihat bahwa adanya kecenderungan penurunan cukup signifikan yang terjadi pada tahun 2018 dengan luas lahan seluas 26,898 Ha atau turun sebesar 34,76 persen dari tahun 2017.

Berbagai bentuk program pembangunan pemerintah sebagai upaya peningkatan ketahanan pangan mengarah pada kedaulatan pangan yang terus dirancang oleh Kementerian Pertanian Indonesia, yang mana jika tercapai upaya peningkatan tersebut di harapkan mampu menggerakkan tumbuh kembang pertanian di Indonesia. Program Asuransi Usaha Tani Padi adalah sebuah 
program yang dirancang pemerintah guna mengatasi kerugian yang dialami petani. Asuransi Usaha Tani Padi mulai di perkenalkan sejak tahun 2015, dimana program asuransi usaha tani padi ialah sebuah upaya peralihan risiko yang mampu memberikan ganti rugi atas dampak dari kerugian usahatani sehingga kontinuitas usahatani dapat terlindungi.

Aceh adalah salah satu daerah yang telah mengimplementasikan program Asuransi Usaha Tani Padi (AUTP) terhitung mulai tahun 2015. Pertumbuhan AUTP di Provinsi Aceh masih tergolong rendah dari target yang dicanangkan seluas 10.000 Ha dan terealisasi hanya 24,49 persen atau sebesar 2.448,09 Ha. Penurunan tertinggi terjadi di tahun 2018, dimana luas lahan yang terealisasi hanya sebesar 5,03 persen atau 503,86 Ha saja. Kerusakan saat pemanenan yang diakibatkan oleh kekeringan, banjir, serta ledakan hama dan penyakit terjadi secara sporadis di beragam daerah di Aceh khususnya Kabupaten Aceh Besar. Ketidakpastian serta besarnya risiko yang mengancam sangat berpotensial memungkinkan petani berganti menjalankan komoditas lain yang memiliki nilai ekonomis tinggi dengan risiko kegagalan yang lebih sedikit. Jika hal ini terus berlangsung, dikhawatirkan akan berakibat pada ketahanan pangan dan stabilitas daerah, khususnya ketersediasan bahan pokok dan produksi beras dalam daerah.

Kabupaten Aceh besar khususnya Kecamatan Suka Makmur merupakan daerah dengan angka klaim asuransi tertinggi atas kegagalan panen yang dialami petani. Kecamatan Suka Makmur mendapatkan klaim terbesar dengan jumlah kerusakan lahan sebanyak 163,49 Ha. Petani yang mendapatkan klaim terdiri dari 24 kelompok tani dengan kerusakan terbesar diakibatkan oleh kekeringan. Beberapa penelitian terkait kesediaan petani untuk membayar (Willingness To Pay) telah banyak dilakukan di Indonesia, antara lain oleh (Riana et al. 2019) Hasil penelitiannya menunjukkan 88 persen responden secara suka rela bersedia lebih membayar dengan peningkatan antara 5 persen sampai dengan 25 persen berdasarkan anggaran beras organik saat ini. Faktor yang dibuktikan signifikan berpengaruh terhadap kesediaan membayar responden yaitu pendapatan, merek beras organik serta harga. Sementara hasil penelitian (SURNING et al. 2018) menunjukkan bahwa besaran iuran premi AUTP yang ditetapkan melalui pendekatan Willingness to Pay (WTP) petani adalah Rp 30.853/Ha/MT, sedangkan iuran premi AUTP yang berlaku saat ini adalah Rp 36.000/Ha/MT, sehingga dapat dikatakan bahwa petani responden menginginkan iuran premi AUTP diturunkan. Hal ini disebabkan oleh munculnya berbagai permasalahan saat pelaksanaan program AUTP.

Terkait pelaksanaan asuransi pertanian, Dinas Pertanian dan Perkebunan Aceh (2019) juga mengemukakan program asuransi usaha tani belum banyak diminati petani di Provinsi Aceh, premi yang ditawarkan sebesar Rp 36.000,/Ha/MT yang wajib dibayarkan dirasa cukup besar oleh petani. Kendati sudah diberikan bantuan pemerintah dengan pemberian subsidi sebesar Rp 144.000,- 
/Ha/MT dari jumlah premi sebesar Rp 180.000,-/Ha/MT, namun mayoritas petani masih enggan ikut serta dalam program asuransi pertanian ini. Membayar premi sebesar 20 persen masih di anggap sulit untuk dilakukan petani, sedangkan plafon penjaminan yang diberikan sebesar Rp 6.000.000,-/Ha/MT dinilai masih kurang sebab klaim yang akan diterima, dianggap hanya cukup untuk membiayai pupuk ataupun bibit saja.

Luas area tanam yang sempit ditambah biaya produksi tinggi berdampak petani butuh adanya jaminan atas beragam risiko dan kerugian yang mungkin diderita akibat suatu bencana atau kejadian tidak terduga. Jika premi subsidi yang ditetapkan oleh pemerintah saat ini masih dinilai cukup tinggi, maka hal ini perlu dikaji kembali sejauh mana petani di Desa Tampok Blang Kecamatan Suka Makmur Kabupaten Aceh Besar bersedia menerima program Asuransi Usaha Tani Padi (AUTP).

Berdasarkan uraian diatas, penelitian ini mencoba untuk menganalisis nilai Willingness To Pay atau kesediaan petani Desa Tampok Blang Kecamatan Suka Makmur, Kabupaten Aceh Besar Untuk Membayar premi AsuransiUsaha Tani Padi (AUTP). Serta, mengidentifikasi dan menganalisis faktor-faktor yang mempengaruhi kesediaan petani untuk membayar (Willingness To Pay) terhadap premi asuransi usaha tani padi di Desa Tampok Blang Kecamatan Suka Makmur, Kabupaten Aceh Besar. Hasil penelitian diharapkan dapat memberikan tambahan informasi kepada pemerintah dan penyuluh tentang kondisi petani dilapangan saat mengikuti program Asuransi usaha Tani Padi (AUTP), sehingga dapat menjadi perbaikan untuk ke depan.

\section{METODOLOGI}

\section{Lokasi dan Waktu Penelitian}

Penelitian ini dilakukan di Desa Tampok Blang Kecamatan Suka Makmur, Kabupaten Aceh Besar. Penelitian dilakukan pada Bulan Februari hingga Mei tahun 2020.

\section{Metode Pengumpulan Data}

Data yang digunakan ialah data primer dan data sekunder. Data primer dikumpulkan melalui pengamatan lapangan (observasi) dan wawancara mendalam terhadap petani padi sawah sebanyak 50 orang responden yang terdiri atas 36 orang petani responden peserta Asuransi Usaha Tani padi (AUTP) dan 14 orang petani responden non peserta Asuransi Usaha Tani Padi (AUTP) survei dilakukan di Desa Tampok Blang Kecamatan Suka Makmur Kabupaten Aceh Besar. Wawancara terhadap petani responden dilakukan dengan menggunakan kuesioner terstruktur. Data sekunder diperoleh dari Dinas Pertanian dan Perkebunan Provinsi Aceh, PT. Jasindo dan Badan Pusat Statistik Provinsi Aceh. Berdasarkan ketersediaan data, maka data yang digunakan yaitu data produksi dan luas panen padi sawah januari 2009 hingga Desember 2018. 


\section{Analisis Data}

Adapun teknik analisis data yang digunakan dalam penelitian ini adalah analisis Contingent Valuation Methode (CVM) dan Persamaan regresi logistik.

\section{Contingent Valuation Methode (CVM)}

Adapun untuk menetapkan nilai WTP melaui pendekatan Contingent Valuation Method (CVM) dapat dilaksanakan dengan langkah-langkah sebagai berikut (Fauzi 2006):

\section{Membangun Pasar Hipotesis}

Risiko kegagalan panen akibat banjir, kekeringan serta organisme pengganggu tanaman (OPT) padi sawah di Desa Tampok Blang Kecamatan Suka Makmur, Kabupaten Aceh Besar merupakan dasar pembentukan pasar hipotesis dalam penelitian ini. Adapun dibutuhkannya bentuk antisipasi untuk membantu petani dalam menangani risiko kegagalan panen tersebut.

\section{Menciptakan/Menghasilkan Nilai Tawaran (Bids Value)}

Besarnya penawaran nilai WTP di peroleh melalui wawancara langsung. Teknik ini dilakukan agar memperoleh nilai penawaran yaitu Open-ended Question yang dilaksanakan dengan cara menyampaikan pertanyaan terbuka pada responden mengenai berapakah nilai yang ingin atau mampu dibayarkan untuk memperoleh ganti rugi dari pemerintah.

\section{Menghitung Nilai Rata-Rata WTP}

Sebelum mengestimasi nilai rataan WTP diperlukannya memperhatikan ada tidaknya nilai yang bias dari nilai rataan (outlier). Nilai rata-rata WTP diestimasi dengan menggunakan persamaan berikut.

$$
E W T P=\sum_{i=1}^{n}(W i P f i)
$$

Dimana:

E WTP : Dugaan rataan nilai WTP

(Rp)

Wi : Nilai WTP ke-I (Rp)

Pfi : Frekuensi relatif (\%)

n : Jumlah responden

I : Responden ke-I yang

bersedia membayar premi

AUTP 


\section{Mengagreratkan Data}

Mengagregatkan total nilai WTP dihitung menggunakan nilai rata-rata WTP yang dikalikan dengan jumlah populasi. Perhitungan nilai total WTP dihitung menggunakan persamaan berikut:

$$
\mathrm{TWTP}=\sum_{i=i}^{n} W \operatorname{TPi}\left(\frac{n i}{N}\right) P
$$

\section{Dimana:}

TWTP

:Total WTP

WTPi

$$
\text { (Rp/Ha/MusimTanam) }
$$

$\mathrm{Ni} \quad$ : Jumlah sampel ke-i yang

bersedia membayar sebesar

WTP

n : Jumlah sampel

P : Jumlah populasi

I $\quad$ : Responden ke-1 yang bersedia membayar $\quad(i=1,2 \ldots n)$

\section{Analisis Regresi Logistik}

Analisis Regresi logistik (Logistic Regression Model) adalah salah satu persamaan dari analisis regresi yang meninjau hubungan antara pengaruh variabel bebas terhadap variabel terikat melalui suatu persamaan matematis tertentu. Regresi logistik dapat dikatakan juga sebagai sebuah analisis univariate atau multivariate yang difungsikan untuk mengestimasi variabel dependen yaitu kemungkinan dari sebuah kejadian dengan menggunakan satu atau lebih variabel independen (Iban \& Indriani 2019)

Model analisis regresi logistik ditentukan untuk mengetahui peluang responden bersedia ataupun tidak bersedia membayar premi AUTP, dimana ada beberapa variabel yang ditaksir akan mempengaruhinya. Variabel yang dimasukkan ke dalam analisis regresi logit ini adalah pengalaman tani, luas lahan, jumlah tanggungan, status lahan dan pendapatan. Bentuk model logistiknya yang akan di gunakan adalah :

$$
\mathrm{Y}=\beta_{0}+\beta_{1} \mathrm{~PB}+\beta_{2} \mathrm{LL}+\beta_{3} \mathrm{ST}+\beta_{4} \mathrm{JT}+\beta_{5} \mathrm{PDPT}+\mathrm{e}
$$

Dimana :

Y $\quad$ : $\quad$ Kesediaan petani membayar premi AUTP

Apabila : 1 petani bersedia membayar premi AUTP 0 petani tidak bersedia membayar premi AUTP

: Konstanta

.. $\quad$ : Koefisien Regresi

PB : : Pengalaman Bertani (Tahun)

LL : Luas Lahan (ha)

ST : Status Lahan ( bernilai 0 jika menyewa, bernilai 1 jika milik 


$\begin{array}{lll} & & \text { pribadi) } \\ \text { JT } & : & \text { Jumlah Tanggungan (org) } \\ \text { PDPT } & : & \text { Pendapatan (Rp/MT) } \\ \varepsilon & : & \text { Galat }\end{array}$

\section{Pengujian Parameter}

Uji statistk umumnya digunakan untuk mengetahui kebaikan dari sebuah model. Pengujian parameter yang dilakukan pada penelitian ini yaitu Uji Serentak, Uji Hosmer and Lemeshow's goodness of fit tesst, Uji Nagelkerke Rsquare, Uji Multikolineritas dan Uji Wald. Adapun pengujian parameter dijelaskan sebagai berikut:

\section{Uji Serentak}

Pengujian model $\mathrm{G}$ dilakukan untuk mengamati pengaruh variabel bebas terhadap variabel terikat secara serentak maupun secara keseluruhan. Adapun uji serentak ini juga disebut sebagai model Chi-Square.

Hipotesis untuk pengujian ini sebagai berikut:

Paling sedikit ada satu parameter 0

Selanjutnya statistik uji G atau Likelihood ratio Test:

$$
\mathrm{G}=-2 \ln \left[\frac{\left(\frac{n^{1}}{n}\right)^{n_{1}}\left(\frac{n^{0}}{n}\right)^{n_{0}}}{\cap n_{i=1} \pi_{i}^{y_{i}}\left(1-\pi_{i}\right)^{1-y_{i}}}\right]
$$

Dimana :

Banyaknya observasi yang berkategori 0

Uji G mengikuti distribusi chi-square, sehingga untuk mendapatkan hasil dilakukan perbandingan dengan nilai tabel, dengan derajat kebebasan $(\mathrm{db})=\mathrm{k}$ $1, \mathrm{k}$ adalah jumlah variabel bebas. Adapun kriteria tolak jika nilai $\mathrm{G}>$ atau jika nilai Sig $<\alpha$ (Timur et al. 2014).

\section{Meperhitungkan Kelayakan Model Regresi}

1. Uji Hosmer and Lemeshow's goodness of fit test

Melakukan pengujian kelayakan suatu model regresi diukur menggunakan Hosmer and Lemeshow's Goodness of Fit Test, dengan kategori yang telah ditentukan sebagai berikut:

- Jika diketahui nilai Hosmer and Lemeshow's Goodness of Fit Test sama dengan atau kurang dari 0,05 diartikan terdapat perbedaan yang signifikan antara model dengan nilai observasinya sehingga Goodness fit model tidak dapat memperhitungkani nilai observasinya.

- Jika diketahui nilai Hosmer and Lemeshow's Goodness of Fit Test lebih besar dari 0,05 diartikan model mampu memperhitungkan nilai observasinya atau dapat dikatakan model dapat diterima karena sesuai dengan data observasinya. 
2. Koefisien Determinan (Nagelkerke R Square)

Nagelkerke $R$ Square adalah sebuah metode uji yang dilaksanakan guna mengestimasi besaran variabel independen mampu menjelaskan serta mempengaruhi variabel dependen. Nilai Nagelkerke $R$ Square beragam antara 1 sampai dengan 0 . Saat nilai semakin mendekati 1 maka model ditafsir semakin sesuai, adapun jika semakin mendekati 0 maka model ditafsir tidak sesuai (Imam Ghozali 2011).

\section{Uji Multikolinearitas}

Uji multikolineritas memiliki tingkat korelasi yang cukup tinggi antara dua variabel bebas yaitu $r>0,8$. Ketika hal ini terpenuhi maka diperkirakan terjadinya masalah multikolinearitas pada persamaan tersebut. Diketahui bahwa multikolinearitas terdiri dua kategori, ayitu multikolineritas tidak sempurna apabila $r<1$ dan multikolineritas sempurna apabila $r=1$.

\section{Uji Wald}

Pengujian wald dilaksanakan setelah dilakukan uji signifakn model yang menentukan bahwa paling tidak terdapat satu variabel bebas yang memiliki pengaruh terhadap variabel terikat. Tujuannya ialah agar mengetahui variabel bebas manakah yang teridentifikasi signifikan mempengaruhi variabel terikat. Barometer pengujian (koefisien $\beta$ ) secara parsial dilakukan menggunakan uji wald dengan syarat berikut:

- Jika diketahui nilai signifikan dari $\mathrm{W}<0,1$ maka variabel independen secara parsial mempengaruhi secara signifikan terhadap variabel dependen.

- Jika diketahui nilai signifikan dari $\mathrm{W}>0,1$ maka variabel independen secara parsial tidak mempengaruhi secara signifikan terhadap variabel dependen (Rahmi \& , 2017).

\section{HASIL DAN PEMBAHASAN}

\section{Kesediaan Petani Untuk Membayar (Willingness To Pay) Pelaksanaan Program Sauransi Usaha Tani Padi (AUTP)}

Analisis kesediaan membayar (Willingness To Pay) digunakan untuk mengetahui tingkat kemampuan membayar petani untuk mengikuti Asuransi Usaha Tani Padi (AUTP) dimana tingkatan harga yang ditawarkan merupakan harga yang sanggup dan mampu yang ingin dibayar oleh petani. Jumlah premi asuransi usaha tani padi saat ini adalah Rp 36.000-/Ha/MT atau senilai 20 persen dari jumlah pertanggungan sebesar Rp 144.000,-/Ha/MT dari total premi sebesar Rp 180.000,-/Ha/MT dan besaran premi ini sepenuhnya dibayarkan oleh pemerintah melalui subsidi (APBN). Pada saat dilakukannya survei, petani diberikan pertanyaan terkait jumlah premi yang mereka sedia bayarkan. 
Berdasarkan hasil penelitian, setelah dilakukan wawancara terhadap petani responden, didapatkan estimasi besarnya nilai kesediaan membayar premi Asuransi Usaha Tani Padi berdasarkan hasil analisis menggunakan pendekatan Contingent Valuation Method (CVM) dapat dilihat sebagai berikut :

1. Pembentukan Pasar Hipotetik (Hypothetical Market)

Berdasarkan hasil survei yang dilakukan terhadap petani responden di Desa Tampok Blang Kecamatan Suka Makmur Kabupaten Aceh Besar tentang kesediaan petani untuk membayar premi Asuransi Usaha Tani Padi (AUTP), diketahui bahwa dari jumlah petani responden yang bersedia melakukan WTP tersebut, sebanyak 44 petani responden dari 50 petani responden bersedia membayar premi AUTP. Sedangkan terdapat 6 petani responden mengatakan tidak bersedia membayar premi AUTP disebabkan berbagai alasan serta diduga masih rendahnya tingkat kesadaran terhadap manfaat dari program AUTP. Berikut ini merupakan persentase petani responden yang bersedia dan tidak bersedia membayar premi AUTP dapat dilihat pada Tabel 1.

Tabel 1. Kesediaan Petaani Responden Untuk Membayar Premi (WTP) Terhadap Premi Asuransi Usaha Tani Padi (AUTP)

\begin{tabular}{cccc}
\hline No & Kesediaan & $\begin{array}{c}\text { Responden } \\
\text { (Orang) }\end{array}$ & $\begin{array}{c}\text { Persentase } \\
\mathbf{( \% )}\end{array}$ \\
\hline 1 & Bersedia & 44 & 88 \\
\hline 2 & Tidak Bersedia & 6 & 12 \\
\hline & Total & $\mathbf{5 0}$ & $\mathbf{1 0 0}$ \\
\hline
\end{tabular}

Sumber: Analisis data primer, 2020 (data diolah).

2. Perolehan Nilai Penawaran (Obtaining Bids)

Berdasarkan nilai lelang yang telah diperoleh melalui survei langsung dalam bentuk kuesioner. Mayoritas nilai lelang diperoleh melalui teknik open ended question (pertanyaan terbuka), yaitu responden menjawab langsung nilai maksimal yang bersedia dibayarkan. Berikut nilai WTP, jumlah responden dan frekuensi kumulatif petani yang bersedia membayar premi AUTP dapat dilihat pada Tabel 2.

Tabel 2. Nilai WTP, Jumlah Responden dan Frekuensi Kumulatif

\begin{tabular}{ccccc}
\hline $\begin{array}{c}\text { Premium } \\
(\mathbf{\%})\end{array}$ & $\begin{array}{c}\text { Nilai WTP } \\
(\mathbf{R} \mathbf{p})\end{array}$ & $\begin{array}{c}\text { Jumlah } \\
\text { Responden }\end{array}$ & $\begin{array}{c}\text { Persentase } \\
\mathbf{( \% )}\end{array}$ & $\begin{array}{c}\text { Frekuensi } \\
\text { Kumulatif }\end{array}$ \\
\hline 11.11 & 20.000 & 10 & 23 & 23 \\
\hline 16.67 & 30.000 & 4 & 9 & 32 \\
\hline 20 & 36.000 & 15 & 34 & 66 \\
\hline 22.22 & 40.000 & 15 & 34 & 100 \\
\hline \multicolumn{7}{c}{ Total } & $\mathbf{4 4}$ & $\mathbf{1 0 0}$ & \\
\hline
\end{tabular}

Sumber: Analisis data primer, 2020 (data diolah). 
Berdasarkan Tabel 2 dapat diketahui sebaran harga yang bersedia dibayarkan petani responden terhadap premi AUTP. Nilai terendah yang bersedia petani responden bayarkan yaitu sebesar Rp 20.000,-/Ha/MT dan nilai tertinggi yang bersedia petani responden bayarkan adalah sebesar Rp 40.000,/Ha/MT. Sebanyak 14 petani responden bersedia membayar premi AUTP lebih rendah dari jumlah premi saat ini sedangkan sebanyak 30 petani responden bersedia membayar lebih tinggi dari jumlah premi yang telah ditetapkan saat ini.

Sebanyak 15 petani responden atau sekitar 34 persen petani responden bersedia untuk membayarkan premi asuransi usaha tani padi sebesar nilai premi saat ini yaitu Rp 36.000,-/Ha/MT atau sebesar 20 persen dari nilai total pertanggungan saat ini dan bersedia membayar premi asuransi pada nilai tawaran awal (initial bid).

Selanjutnya diketahui sebanyak 15 petani responden atau sekitar 34 persen menyatakan bersedia untuk membayar premi asuransi dengan tawaran harga pertama yang lebih tinggi (first higher bid) yaitu sebesar Rp 40.000,-/Ha/MT atau senilai 22,22 persen dari nilai total pertanggungan saat ini dan bersedia membayar premi asuransi diatas nilai tawaran awal (initial bid).

Selanjutnya terdapat 4 petani responden atau sekitar 9 persen petani bersedia untuk membayar premi asuransi dengan tawaran harga pertama yang lebih rendah (first lower bid) senilai Rp 30.000,-/Ha/MT atau sebesar 16.67 persen dari nilai total pertanggungan saat ini dan bersedia membayar premi asuransi dibawah nilai tawaran awal (initial bid) dan 10 petani responden atau sekitar 23 persen petani bersedia untuk membayar dengan tawaran harga kedua yang lebih rendah (second lower bid) senilai Rp 20.000,-/Ha/MT atau sebesar 11.11 persen dari nilai total pertanggungan saat ini dan bersedia membayar premi asuransi dibawah nilai tawaran awal (initial bid).

\section{Menghitung Dugaan Nilai Rataan WTP}

Dugaan nilai rataan WTP (EWTP) responden diestimasi berdasarkan data distribusi WTP responden dengan menggunakan rumus EWTP. Nilai tersebut dijadikan tingkatan serta diurutkan dari terkecil sampai terbesar. Data distribusi WTP responden dapat dilihat pada Tabel 3.

Tabel 3. Tingkatan nilai WTP, Jumlah Responden, dan Frekuensi Relatif Petani

\begin{tabular}{ccccc} 
Nesponden & & & & \\
\hline $\mathbf{N}$ & $\begin{array}{c}\text { Tingkatan WTP } \\
\text { (Rp/Ha/MT) }\end{array}$ & $\begin{array}{c}\text { Jumlah } \\
\text { Responden }\end{array}$ & $\begin{array}{c}\text { Frekuensi } \\
\text { Relatif }\end{array}$ & $\begin{array}{c}\text { EWPT } \\
\text { (Rp/Ha/MT) }\end{array}$ \\
\hline $\mathbf{1}$ & 20000 & 10 & 0,23 & 4.600 \\
\hline $\mathbf{2}$ & 30000 & 4 & 0,09 & 2.700 \\
\hline $\mathbf{4}$ & 36000 & 15 & 0,34 & 12.240 \\
\hline & 40000 & 15 & 0,34 & 13.600 \\
\hline
\end{tabular}

Sumber: Analisis data primer, 2020 (data diolah). 
Berdasarkan Tabel 3 menunjukkan bahwa rataan maksimum nilai WTP petani responden terhadap premi AUTP adalah sebesar Rp 33.140/Ha/MT atau sebesar 18,4 persen dari total premi keseluruhan sebesar Rp 180.000/Ha/MT. Nilai WTP yang didapatkan lebih rendah sebesar Rp 2.860,- atau 2,2 persen jika dibandingkan dengan premi swadaya yang ditetapkan pemerintah saat ini yaitu berkisar 20 persen dari jumlah total premi asuransi usaha tani padi (AUTP).

\section{WTP Agregat atau Total WTP (TWTP)}

Nilai total (TWTP) petani responden diestimasi berdasarkan data distribusi WTP responden dan menggunakan rumusan nilai total WTP. Hasil estimasi nilai TWTP dapat dilihat pada Tabel 4.

Tabel 4. Perhitungan Nilai WTP

\begin{tabular}{cccc}
\hline No & $\begin{array}{c}\text { Maksimum WTP } \\
(\mathbf{R} \text { ) }\end{array}$ & $\begin{array}{c}\text { Jumlah } \\
\text { Responden }\end{array}$ & $\begin{array}{c}\text { TWTP } \\
(\mathbf{R} \text { ) }\end{array}$ \\
\hline 1 & 20000 & 10 & 200.000 \\
\hline 2 & 30000 & 4 & 120.000 \\
\hline 3 & 36000 & 15 & 540.000 \\
\hline 4 & 40000 & 15 & 600.000 \\
\hline & Total & $\mathbf{4 4}$ & $\mathbf{1 . 4 6 0 . 0 0 0}$ \\
\hline
\end{tabular}

Sumber: Analisis data primer, 2020 (data diolah).

Berdasarkan Tabel 4 diketahui bahwa nilai TWTP yaitu nilai kesediaan untuk membayar dari seluruh sampel penelitian yang berjumlah 44 petani responden. Berdasarkan pada hasil perhitungan didapatkan nilai total WTP untuk 44 petani responden yang menyatakan bersedia membayar premi AUTP adalah sebesar Rp 1.460.000//Ha/MT serta untuk nilai total WTP pertahunnya untuk 2 kali musim tanam ialah sebesar Rp. 2.920.000/Ha/Tahun.

\section{Faktor-Faktor Yang Mempengaruhi Kesediaan Untuk Membayar (Willingness} To Pay) dengan Analisis Persamaan Logistik

Metode analisis yang digunakan untuk melihat pengaruh variablevariabel independen terhadap peluang yang mempengaruhi variabel dependen dalam model penelitian ini yaitu dapat dijelaskan berdasarkan hasil persamaan Regresi Logistik atau fungsi logit dengan menggunakan SPSS versi 17. Penggunaan alat analisis regresi logistik (logistick regression) adalah disebabkan variabel dependen bersifat biner/lebih dari 1 sifat (petani bersedia atau tidak bersedia membayar premi AUTP). Sedangkan asumsi normal distribusi yang biasanya digunakan tidak perlu dipenuhi sebab variabel bebas adalah variabel campuran antara kontinu (metrik) dan kategorik (non-metrik). Keadaan seperti ini dapat dianalisis dengan regresi logistik yang mana regresi ini tidak diperlukannya uji asumsi normalitas data pada variabel bebas (Imam Ghozali 2011) Analisis regresi logistik menggunakan 5 variabel independen dan diperoleh hasil bahwa terdapat 2 variabel yang berpengaruh secara signifikan 
terhadap kesediaan petani untuk membayar (WTP) premi AUTP dengan taraf signifikan $\alpha=5 \%$ dan $10 \%$. Hasil pengujian regresi logistik dapat dilihat sebagai berikut:

\section{a) Hasil Uji Serentak}

Uji serentak dilaksanakan untuk menguji tingkat signifikansi sebuah model dalam suatu penelitian. Adapun hasil dari analisis Uji G dapat dilihat pada Tabel 5 .

Tabel 5. Uji signifikansi parameter secara serentak

\begin{tabular}{llccc}
\hline & & Chi-Square & Df & Sig \\
\hline \multirow{2}{*}{ Step 1 } & Step & 15,112 & 5 &, 010 \\
\cline { 2 - 5 } & Block & 15,112 & 5 &, 010 \\
\cline { 2 - 5 } & Model & 15,112 & 5 &, 010 \\
\hline
\end{tabular}

Sumber: Analisis data primer, 2020 (data diolah).

Berdasarkan Tabel 5 diketahui bahwa nilai statistik uji $G$ yang dihasilkan dalam model diperoleh nilai $G$ sebesar 15,112 dengan menggunakan $\alpha=5 \%$. Maka diperoleh nilai, hal ini menunjukkan $G>$ maka tolak yang diartikan bahwa paling sedikit ada satu parameter dimana terdapat satu atau lebih variabel bebas yang berpengaruh signifikan secara serentak atau secara keseluruhan terhadap variabel terikat.

\section{b) Hasil Goodness of Fit}

1. Hosmer and Lemeshow's Test

Pemodelan estimasi statistik Hosmer and Lemeshow memberikan informasi terkait kualitas penggunaan model statistik. Adapun hasil analisis Hosmer and Lemeshow dapat dilihat pada Tabel 6 sebagai berikut.

Tabel 6. Hosmer and Lemeshow's Test

\begin{tabular}{llll}
\hline & Chi-square & Df & Sig \\
\hline Step 1 & 3.010 & 8 & 0,934
\end{tabular}

Sumber: Analisis data primer, 2020 (data diolah).

Berdasarkan Tabel 6 diketahui bahwa tingkatan signifikansi observasi untuk nilai chi-square $\left(\mathrm{x}^{2}\right)$ yang didapatkan adalah 3.010 dan nilai sig yaitu sebesar $0,934>\alpha(0,05)$. Hal ini mengartikan bahwa model dapat memperkirakan nilai observasi atau dapat dikatakan model dapat diterima untuk dilanjutkan dikarenakan sesuai dengan data observasi.

\section{2. $\quad$ Uji Nagelkerke R Square}

Pengukuran keeratan hubungan antara variabel independen dengan variabel dependen juga dihitung menggunakan Cox and Snell $R$ Square and Nagelkerke R Square. Nagelkerke's R Square merupakan transformasi lanjutan untuk 
koefisien Cox and Snell's untuk menetapkan bahwa kisaran nilainya antara 1 dan 0. Umumnya nilai Nagelkerke's lebih besar dari pada nilai Cox and Snell's. Hasil analisis Nagelkerke's dapat dilihat pada Tabel 7.

Tabel 7. Nagelkerke R Square

\begin{tabular}{cccc}
\hline & $\mathbf{- 2 ~ L o g ~ L i k e h o o d}$ & Cox $\&$ Snell R Square & Nagelkerke R Square \\
\hline Step 1 & $21.580^{a}$ & 0,241 & 0,502 \\
\hline
\end{tabular}

umber: Analisis data primer, 2020 (data diolah).

Berdasarkan Tabel 6 diketahui bahwa nilai Nagelkerke $R$ Square ialah sebesar 0.502. Nilai ini membuktikan kekuatan model yang digunakan dalam penelitian. Berdasarkan nilai yang didapat dijelaskan bahwa variabel independen mampu menjelaskan variabel dependen sebesar 50,2 persen, sedangkan 49,8 persen dijelaskan oleh variabel lain diluar model.

3. Uji Multikolineritas Matriks

Uji korelasi dilakukan untuk mengetahui apakah terjadinya multikolineritas antar variabel-variabel yang digunakan dalam model penetlitian ini. Adapun hasil analisis pengujian Multikolineritas dapat dilihat pada Tabel 8 sebagai berikut.

Tabel 8. Correlation Matrix

\begin{tabular}{|c|c|c|c|c|c|c|c|}
\hline & & Konstanta & $\mathrm{X} 1$ & $\mathrm{X} 2$ & $\mathrm{X} 3$ & $\mathrm{X} 4$ & $\mathrm{X} 5$ \\
\hline \multirow{6}{*}{ Step 1} & Konstanta & 1,000 & $-0,148$ & $-0,232$ & $-0,236$ & $-0,093$ & $-0,555$ \\
\hline & Pengalaman Tani & $-0,148$ & 1,000 & 0,507 & $-0,080$ & 0,007 & $-0,387$ \\
\hline & Luas Lahan & $-0,232$ & 0,507 & 1,000 & 0,032 & 0,351 & $-0,663$ \\
\hline & Status Lahan & $-0,236$ & $-0,080$ & 0,032 & 1,000 & 0,219 & 0,077 \\
\hline & $\begin{array}{l}\text { Jumlah } \\
\text { Tanggungan }\end{array}$ & $-0,093$ & 0,007 & 0,351 & 0,219 & 1,000 & $-0,335$ \\
\hline & Pendapatan & $-0,0555$ & $-0,387$ & $-0,663$ & 0,077 & $-0,335$ & 1,000 \\
\hline
\end{tabular}

Sumber: Analisis data primer, 2020 (data diolah).

Pada Tabel 8 diketahui matriks hubungan membuktikan bahwa tidak adanya gejala multikolineritas serius yang terjadi antara variabel bebas, sebagaimana dapat dilihat pada nilai korelasi antar variabel bebas yang bernilai di bawah 0.8 .

\section{c) Hasil Analisis Classification Table}

Adapun pengujian validitas pada model ini menggunakan tabel klasifikasi (Classification Table) guna memperlihatkan apakah benar atau tidaknya sebuah model dalam suatu penelitian. Keputusan yang didapatkan pada tabel klasifikasi ialah tingkat sensivitas model yang dapat dilihat pada tabel 9 sebagai berikut. 
Tabel 9. Tabel Klasifikasi

\begin{tabular}{|c|c|c|c|c|c|}
\hline & \multirow{3}{*}{ Observed } & & \multicolumn{3}{|c|}{ Predicted } \\
\hline & & & \multicolumn{2}{|c|}{ Kesediaan Membayar } & \multirow{2}{*}{$\begin{array}{l}\text { Percentag } \\
\text { e Correct }\end{array}$} \\
\hline & & & $\begin{array}{c}\text { Tidak } \\
\text { Bersedia }\end{array}$ & Bersedia & \\
\hline \multirow[t]{3}{*}{ Step 1} & \multirow{3}{*}{$\begin{array}{l}\text { Kesediaan } \\
\text { Membayar }\end{array}$} & Tidak & 4 & 2 & 66,6 \\
\hline & & Bersedia & & & \\
\hline & & Bersedia & 1 & 43 & 97,7 \\
\hline & $\begin{array}{c}\text { Overall } \\
\text { Percentage }\end{array}$ & & & & 94,0 \\
\hline
\end{tabular}

a. The cut value is, 500

Berdasarkan pada Tabel 9 dapat diketahui bahwa tingkat persentase ketepatan model dalam mengelompokkan responden berdasarkan kesedian atau ketidaksediaan membayar premi AUTP adalah 94 persen. Hal ini dapat diartikan dari 50 jumlah petani responden, terdapat 47 petani responden yang tepat diklasifikasikan dengan model regresi logistik. Hasil klasifikasi regresi ini membuktikan bahwa terdapat 6 petani responden tidak bersedia membayar premi AUTP dan terdapat 2 petani responden yang disklasifikasi (salah klasifikasi), yang mana membuktikan ketepatan prediksi sebesar 66,6 persen, sedangkan terdapat 44 petani responden yang bersedia membayar premi AUTP, terdapat 1 petani responden disklasifikasi (salah klasifikasi) serta membuktikan ketepatan prediksi sebesar 97,7 persen.

\section{d) Uji Wald}

Uji wald digunakan untuk memperhitungkan besaran pengaruh variabel independen yang signifikan terhadap variabel dependen. Adapun hasil dari pengujian Wald dapat dilihat pada Tabel 10 sebagai berikut.

Tabel 10. Hasil Uji Koefisien Regresi Logistik

\begin{tabular}{lcccccc}
\hline & B & S.E & Wald & Df & Sig & $\operatorname{Exp(B)}$ \\
\hline Konstanta & $-4,876$ & 14,539 & 0,112 & 1 & 0,737 & 0,008 \\
\hline Pengalaman Bertani & $-0,058$ & 0,088 & 0,435 & 1 & 0,510 & 0,944 \\
\hline Luas Lahan & $-2,183$ & 1,757 & 1,545 & 1 & 0,214 & 0,113 \\
\hline Status Lahan & $-0,411$ & 1,467 & 0,079 & 1 & 0,779 & 0,663 \\
\hline Jumlah Tanggungan & $-1,251$ & 0,508 & 6,058 & 1 & 0,014 & $0,286^{*}$ \\
\hline Pendapatan & 2,244 & 1,339 & 2,807 & 1 & 0,094 & $9,431^{\text {** }}$
\end{tabular}

a. Variabel(s) entered on step $1: \mathrm{X} 1, \mathrm{X} 2, \mathrm{X} 3, \mathrm{X} 4, \mathrm{X} 5$.

Keterangan: *Signifikansi $95 \%$

**Signifikansi $90 \%$

Tabel 10 diketahui bahwa variabel independen yang berpengaruh secara signifikan terhadap kesediaan petani untuk membayar atau tidak membayar premi AUTP adalah variabel jumlah tanggungan (X4) dan variabel pendapatan (X5). Hal ini dapat diartikan nilai variabel X4 dan X5 $<\alpha(0,05$ dan 0,1). Sedangkan variabel Pengalaman Bertani (X1), Luas Lahan (X2) dan Status Lahan 
(X3) tidak mempengaruhi keputusan petani bersedia atau tidak bersedia untuk membayar premi AUTP. Adapun berdasarkan Tabel 10 hasil pengujian terhadap koefisien regresi didapatkan persamaan sebagai berikut:

\section{$\mathrm{Y}=-4,876-0,058 \mathrm{~PB}-2,183 \mathrm{LL}-0,411 S T-1,251 \mathrm{JT}+2,244 \mathrm{PDPT}+\mathrm{e}$}

Nilai konstanta pada kesediaan petani untuk membayar premi AUTP adalah sebesar $-4,876$ yang artinya adalah apabila seluruh variabel yang terdiri dari Pengalaman Bertani, Luas Lahan, Status Lahan, Jumlah Tanggungan dan Pendapatan dianggap konstan atau bernilai nol (0), maka akan menurunkan tingkat kesediaan petani untuk membayar premi AUTP sebesar $-4,876$.

Variabel pengalaman bertani (X1) memiliki nilai P-value sebesar 0,510. Nilai tersebut diartikan bahwa lebih besar dari tingkat signifikansi uji sebesar $5 \%$ atau 0,05 sehingga diterima, yang diartikan bahwa lama bertani yang dilakukan petani responden tidak berpengaruh secara signifikan terhadap kesediaan petani dalam membayar premi AUTP. Koefisien regresi dari variabel pengalaman bertani bernilai negatif. Nilai odds ratio sebesar 0,944 nilai tersebut diartikan bahwa kecenderungan kesediaan petani membayar premi AUTP akan turun sebesar 0,944 kali, setiap peningkatan 1 tahun pengalaman kerja usahatani.

Variabel luas lahan (X2) memiliki nilai P-value sebesar 0,214. Nilai tersebut diartikan bahwa lebih besar dari tingkat signifikansi uji sebesar $5 \%$ atau 0,05 sehingga diterima, yang diartikan bahwa luas lahan yang dikelola oleh petani responden tidak berpengaruh secara signifikan terhadap kesediaan petani dalam membayar premi AUTP. Koefisien estimasi dari variabel luas lahan bernilai negatif. Nilai odds ratio sebesar 0,133, nilai tersebut diartikan bahwa kecenderungan kesediaan petani membayar premi AUTP akan turun sebesar 0,133 kali, setiap peningkatan 1 hektar luas lahan.

Variabel status lahan (X3) yang merupakan variabel dummy memiliki nilai P-value yaitu sebesar 0,779. Nilai tersebut diartikan bahwa lebih besar dari tingkat signifikansi uji sebesar $5 \%$ atau 0,05 sehingga diterima yang diartikan bahwa status lahan yang dimiliki atau disewa oleh petani responden tidak (Azwar et al. 2016)berpengaruh secara signifikan terhadap kesediaan petani dalam membayar premi AUTP. Koefisien estimasi dari variabel luas lahan bernilai negatif. Nilai odds ratio sebesar 0,663, nilai tersebut diartikan bahwa kecenderungan kesediaan petani membayar premi AUTP akan turun sebesar 0,663 kali, setiap peningkatan 1 satuan status lahan.

Variabel jumlah tanggungan (X4) nilai P-value yaitu sebesar 0,014. Nilai ini diartikan bahwa lebih kecil dari tingkat signifikansi 5\% atau 0,05 sehingga ditolak, yang diartikan bahwa jumlah tanggungan petani responden berpengaruh secara signufikan terhadap kesediaan petani dalam membayar premi AUTP. Koefisien estimasi dari variabel jumlah tanggungan bernilai negatif. Nilai odds ratio sebesar 0,286, nilai tersebut diartikan bahwa setiap 
kecenderungan kesediaan petani membayar AUTP akan turun sebesar 0,286 kali, setiap peningkatan 1 orang jumlah tanggungan.

Variabel pendapatan memiliki nilai P-value yaitu sebesar 0,094. Nilai tersebut diartikan bahwa lebih kecil dari tingkat signifikansi uji sebesar 10 persen atau 0,1 sehingga ditolak, yang diartikan bahwa tingkat pendapatan petani responden berpengaruh secara signifikan terhadap kesediaan petani dalam membayar premi AUTP. Koefisien estimasi dari variabel pendapatan bernilai positif. Nilai odds ratio sebesar 9,431, nilai tersebut diartikan bahwa setiap adanya peningkatan Rp 1 pendapatan, maka peluang petani untuk membayar premi AUTP akan naik sebesar 9,431 kali.

\section{Kendala Asuransi Usaha Tani Padi (AUTP)}

Pelaksanaan Asuransi usaha tani padi dari pihak petani sebagai peserta AUTP memiliki beberapa kendala. Adapun kendala dari petani dalam mengikuti pelaksanaan AUTP adalah sebagai berikut:

1. Terkendala adat istiadat dan agama.

2. Kurangnya informasi yang didapatkan terkait asuransi usaha tani padi.

3. Sulitnya persyaratan dan tata cara dalam mengikuti program asuransi usaha tani padi.

\section{Kesimpulan}

\section{KESIMPULAN DAN SARAN}

Terdapat sebanyak 44 responden atau 88 sekitar 88 persen dari total jumlah petani responden petani padi sawah yang dinyatakan berminat dan bersedia untuk membayar premi asuransi usaha tani padi (AUTP) dengan tingkatan harga rata-rata WTP adalah sebesar Rp 33.140/Ha/MT dan nilai total WTP responden sebesar Rp 1.460.000,-/Ha/MT. Hasil perhitungan nilai WTP menunjukkan bahwa responden mampu untuk membayar premi AUTP lebih rendah daripada biaya retribusi yang telah ditetapkan pemerintah saat ini yaitu sebesar Rp 36.000/Ha/MT.

Berdasarkan hasil analisis logistik faktor-faktor yang berpengaruh terhadap peluang kesediaan membayar (Wlingness to Pay) petani di Desa Tampok Blang Kecamatan Suka Makmur Kabupaten Aceh Besar terhadap premi Asuransi Usaha Tani Padi (AUTP) adalah variabel jumlah tanggungan dan pendapatan (pada taraf nyata 5 persen dan 10 persen). Sedangkan pengalaman bertani, luas lahan dan status lahan tidak berpengaruh secara nyata terhadap kesediaan petani untuk membayar (WTP) terhadap premi Asuransi Usaha Tani Padi (AUTP). 


\section{Saran}

Berdasarkan hasil penelitian, disarankan dua hal sebagai berikut, Pertama, di perlukannya peningkatan kesetaraan pengetahuan dan koordinasi informasi antara petani, dinas, penyuluh lapangan, serta semua pihak yang terkait dengan program AUTP sehingga meminimalisisr kesalahpahaman yang terjadi serta lebih memberikan informasi secara detail, ringkas dan mudah dipahami petani sehingga program AUTP dapat dijalankan dengan baik.

Kedua, penyuluh lapangan sebaiknya menambah pertemuaan penyuluhan atau sosialisasi kepada para petani untuk meningkatkan peluang keikutsertaan petani dalam program-program pemerintah kedepannya. Serta diperlukannya upaya peningkatan partisipasi dan keaktifan petani dalam kelompok tani. Dengan adanya peningkatan partisipasi dan keaktifan petani maka akan membangun pengetahuan yang akan meningkatkan pola pikir petani dalam menyikapi suatu inovasi.

\section{UCAPAN TERIMA KASIH}

Penulis bersyukur kepada Allah SWT atas segala karunia-Nya sehingga naskah ini berhasil diselesaikan. Ucapan terima kasih penulis sampaikan kepada semua pihak yang telah mendukung penelitian ini. Kepada Dinas Pertanian dan Holtikultura Provinsi Aceh yang telah memberikan kesedian dalam perolehan data untuk mendukung penelitian ini.

\section{DAFTAR PUSTAKA}

BPS. PA. 2018. Hasil Survei Pertanian Antar Sensus (SUTAS) 2018 Provinsi Aceh. SUTAS T, editor. Aceh: Badan Pusat Statistik Provinsi Aceh.

Dewi N. 2019. Analisis kesediaan membayar premi asuransi usaha tani padi di kabupaten karawang: Sebelas maret.

Fauzi A. 2006. Ekonomi Sumber Daya Alam dan Lingkungan: Teori dan Aplikasi. NA. Jakarta: PT Gramedia Pustaka Utama.

Iban M, Indriani D. 2019. Regression Analysis of Ordinal Logit and Probit Models to Predict the Factors Affecting Low Birth Weight. J Biometrika dan Kependud. 8(1):62.

Imam Ghozali. 2011. Aplikasi Analisis Multivariate Dengan Program IBM SPSS 19 edisi 5. 5th ed. BP Universitas Diponegoro.

Rahmi H, , F. 2017. Faktor-Faktor Yang Mempengaruhi Pengambilan Keputusan Petani Terhadap Penggunaan Benih Padi Di Kecamatan Nisam Kabupaten Aceh Utara. Agrifo J Agribisnis Univ Malikussaleh. 2(2):18.

Riana ET, Mukson M, Roessali W. 2019. Analisis Kesediaan Membayar (Willingness To Pay) Konsumen Terhadap Berbagai Jenis Beras Organik di Kota Semarang (Kasus Di Pasar Modern Gelael Signature). Jurnal Ekonomi Pertan dan Agribisnis. 3(4):689-700.

Sabri F, Amelia R. 2016. Analisis Willingness to Pay (WTP) Dan Kebutuhan Air di Kecamatan Merawang. Infoteknik. 17(2):235-252.

Surning NN, Ambarawati IGAA, Ustriyana ING. 2018. Willingness To Pay 
Petani terhadap Pelaksanaan Asuransi Usaha Tani Padi (AUTP) (Studi Kasus Subak Cepik Desa Tajen Kecamatan Penebel Kabupaten Tabanan). J Agribisnis dan Agrowisata (Journal Agribus Agritourism). 7(3):364.

Timur DA, Wilandari Y, Safitri D. 2014. Ketetapan Klasifikasi Keikutsertaan Keluarga Berencana (KB) Menggunakan Analisis Regresi Logistik Biner dan Fuzzy K-Nearest Neightbor In Every Class Di kabupaten Klaten. J Gaussian. 3(4):615-624. 